\title{
AWAKENING TO THE TRANSPERSONAL PARADIGM: DISCERNING TRANSCENDENT EXPERIENCES FROM PATHOLOGY
}

\section{R Bhagwan}

\section{INTRODUCTION}

Historically social work has shared a tenuous relationship with religion and spirituality. In an effort to hold onto its scientific roots, which began with the quest for professionalisation, it became suspicious of knowledge and experience that could not be fully quantified or rationally derived. It began to "distrust the language of higher transcendence, mystical connection, intuitive grasp" (Besthorn, 2001:38). More recently, however, the profession has become more accepting of spirituality, in the light of evidence that spiritual growth and experiences foster physical and psychological well-being (Pargament, 1997). Parallel to the acceptance of the spiritual paradigm is the growing interest in transpersonal social work, which focuses on empowering the client as well as on spiritual experiences, personal transformation and health (Canda \& Furman, 1999; Cowley, 2001; Cowley \& Derezotes, 1994).

Canda (2001) established the salience of the transpersonal paradigm by stating that people's sense of wellbeing develops through experiences and beliefs in a transpersonal realm, i.e. through enhanced states of consciousness, divine beings and sacred energies for healing that transcend the ordinary limitations of body, ego, space and time. In keeping with this a range of practitioners have begun to weave transpersonal approaches into the treatment of substance use, divorce, bereavement and illness (Smith, 1995; Reese, 2001; Derezotes, 2001).

Despite international discourse in this field, transpersonal social work remains unheard of in South Africa. This paper attempts to address this gap by outlining the basic underpinnings of the transpersonal paradigm and transpersonal development. It also provides a broad overview of the transpersonal experiences that clients may have, their effects and guidelines for the practitioner in terms of discerning spiritual experiences from forms of pathology. Two case examples are presented to highlight these issues.

\section{SPIRITUALITY AND TRANSPERSONALISM DEFINED}

There are a myriad of definitions of spirituality in the literature. Some writers view spirituality as a person's experience of and relationship with a transcendent or ultimate source of creation (Bullis, 1996; Berenson, 1987; Canda, 1988a, 1988b), whilst those who link it with religion view it as a sense of wellbeing in relation to God or within a religious context (Ellison, 1983).

Although there does not appear to be a precise definition of transpersonalism, Lajoie and Shapiro (1992:91) wrote that it relates to "humanity's highest potential, and [the] .... recognition, understanding, and realization of unitive, spiritual, and transcendent states of consciousness". Carroll (2001) makes the connection between spirituality and the transpersonal, by positing that there are two different meanings of spirituality, i.e. spirituality-as-essence and spirituality-as-onedimension. Spirituality-as-essence refers to a core nature, which provides the energy towards meeting the potential for self-development, and spirituality-as-one-dimension refers to a person's search for meaning and relationship with God, the transcendent or ultimate reality. She added that spirituality-as-one-dimension refers to the transpersonal dimension of a person and that the terms God, transcendent, creator, Higher Power and life energy could be used interchangeably to refer to a relationship with the transpersonal. 


\section{The transpersonal paradigm and social work}

The transpersonal paradigm emerged from the ancient wisdom of the East. Together with the psychoanalytic, behavioural and humanistic orientations it provides a model that includes "selftranscendence ...in shaping experience and enhancing well-being" (Walsh \& Vaughan, 1980:5). It is based on the premise that there are significant forces within the self that propel a person towards wholeness, integration and psycho-spiritual transformation. The transpersonal perspective in social work posits that the self has much richer psychological, emotional and transcendent potentialities (Besthorn, 2001). It also argues that through the process of spiritual growth and becoming connected with self, others, God or a transcendent dimension, dysfunction is reduced thereby maximising development in the bio-psycho-social realms (Carroll, 2001).

Cowley (1993) argued that many social workers are encountering clients who are experiencing the "postmodern malady", meaning that they are no longer satisfied by materialism, their abstract irrationality and egoic personalities (Cowley, 1993:28). Clients have become "seduced into the conventional life-style and live in a trance-like state consisting of developmental stagnation with its accompanying existential suffering," attached to a limited view of themselves within their environmental circumstances (Walsh in Leight, 2001:68).

According to Leight (2001:75), the transpersonal, bio-psycho-social-spiritual approach recognises the "status of the human condition in the societal context and works to alleviate existential suffering and disease of the spiritual dimension." She adds that it does this by providing the context, content and process for addressing family and relationships, "environmental, societal, and cultural stressors, non-pathologic transrational phenomena, and the grief associated with human existential suffering" (2001:64). In so doing, it enables oppressed and devalued clients who are most vulnerable to self-alienation. In a similar vein Cowley (1996:680) argued for a comprehensive approach that includes interconnecting the six different facets: the physical, emotional, cognitive, psychosocial, moral and spiritual, so as to create a holistic mind-body-spirit approach when dealing with such strife.

The main focus of transpersonal social work, however, is facilitating the development of the spiritual dimension of individuals and through this development to enable spiritual maturity and higher states of consciousness to evolve (Cowley \& Derezotes, 1994; Washburn, 1988). Having established the salience of this paradigm to practice, this paper will now explore transpersonal development within the context Ken Wilber's model.

\section{Ken Wilber's model of transpersonal development}

Wilber's (1979) model of transpersonal development is based on the premise that human development is the unfolding of higher-order unities and that growth proceeds from the lower realms to ultimate levels of transcendence and integration (1979:2). He postulated that there is a profound drive in humans to evolve toward what he refers to as the self-realisation of the "Spirit" (Wilber in Rothberg \& Kelly, 1998:6).

The psyche has a clear hierarchical structure, with higher levels of reality and development that are superior to the lower levels in the logical and theoretical sense. Each level or stage of development shows newly differentiated emergent qualities in relation to the previous level or stage, qualities that make possible new properties or achievements (Wilber, Engler \& Brown, 1986). Thus at each stage the person's consciousness is able to incorporate more aspects of reality and more modes of functioning.

As increasingly complex and inclusive modes of spirituality are developed, there is a move from the pre-egoic or pre-personal level (early childhood) to an egoic orientation or personal level 
(typically established in adolescence) to trans-egoic or transpersonal levels of development, which can be achieved in adulthood (Wilber et al., 1986). Using Wilber's framework, Cowley (2001) one of the earliest proponents of transpersonal social work, posited that at the prepersonal level of development preparational structures, impulses and primary processes associated with early childhood are common. When such descriptors continue beyond the age of three, then the existence of psychotic, narcissistic and borderline personality disorders are indicated. At the personal level the beginnings of a rational-individuated person, whose sense of identity and relative autonomy are evident, whilst at the transpersonal level a person exhibits character traits such as generativity, altruism, compassion and the capacity for unconditional life. Spiritual and transpersonal experiences as well as mystical and extrasensory perceptions become more common during this stage (Canda \& Furman, 1999).

Wilber (1982) wrote that it is through understanding the pre-personal, personal and transpersonal stages of development that transpersonal development can be understood. More importantly, because the model recognises the possibility of the human ability for self-transcendence and movement from the chaotic pre-personal stages towards those of transpersonal or higher stages of consciousness, transpersonal experiences may be validated. Vaughan (1987) shed more light on the transpersonal level of consciousness or ego transcendence, stating that persons who move to this level reflect: (1) an integrated articulated wholeness compared to an undifferentiated oneness; (2) cognised intuition as compared to a trance or passive unconscious perception; (3) faith and grace as compared to infantile dependence; (4) insight rather than undifferentiated perception; (5) spontaneity as opposed to reactivity and impulsiveness; (6) altruism rather than narcissism; and (7) purity of heart rather than ignorance. It is these characteristics that provide a frame of reference to discern between transpersonal experiences that are healthy and those that are pathological.

Wilber's (1982) model along with the views of other transpersonalists is relevant to social work practice as it provides an integrative framework for understanding both healthy and pathological stages. It also provides practitioners with an alternative to the linear, reductionist frameworks of the biomedical and behavioural models, which limit possibilities for development (Cowley, 1993). Such an understanding is important as clients may bring transcendent or transpersonal experiences into the clinical dialogue.

\section{Types of transpersonal experiences}

Human experience of spirituality is unbounded and has the potential to nurture a range of transcendent experiences, mystical experiences, spiritual awakenings and peak experiences (Bhagwan, 2002). Much of this experience has been couched under the category of transpersonal experience in the literature. Using White's (1998) examples of exceptional human experiences, the author has created a framework to distinguish the different types of transpersonal experiences (Table 1). 
TABLE 1

TYPES OF TRANSPERSONAL EXPERIENCES

\begin{tabular}{|c|c|}
\hline $\begin{array}{l}\text { Broad categories of } \\
\text { transpersonal } \\
\text { experiences }\end{array}$ & Types and features \\
\hline Mystical experiences & $\begin{array}{l}\text { Also referred to as peak experiences (Maslow, 1970) or "flow } \\
\text { experiences" (Csikszentmihalyi, in White, 1998:132), when they } \\
\text { occur in a non-religious context. Spiritual awakenings that are } \\
\text { characterised by overwhelming feelings of happiness, an ecstatic joy } \\
\text { that fills the person with a deep sense of peace and security } \\
\text { (Bloomfield, 1980) all fall in this category. }\end{array}$ \\
\hline Psychic experiences & $\begin{array}{l}\text { Forms of extrasensory perception, viz. ESP, clairvoyance, telepathy, } \\
\text { precognition and telekinesis. They provide an understanding that } \\
\text { humans literally may not be separated from others, especially from } \\
\text { those with whom we are intimate, by distance or time (White, 1998). }\end{array}$ \\
\hline $\begin{array}{l}\text { Death-related } \\
\text { Experiences }\end{array}$ & $\begin{array}{l}\text { Consist of near-death experiences, death-bed experiences and } \\
\text { experiences in which people see and meet with their deceased loved } \\
\text { ones (Ring, 1984; Canda \& Furman, 1999). }\end{array}$ \\
\hline $\begin{array}{l}\text { Encounter } \\
\text { experiences }\end{array}$ & $\begin{array}{l}\text { Experiences of observing and sometimes interacting with apparitions } \\
\text { and alien beings. Includes encounters with UFOs, angels, religious } \\
\text { figures and other anomalous phenomena (White, 1998). } \\
\text { Communication with spirits of ancestors, deceased loved ones, and } \\
\text { spirit powers associated with nature. } \\
\text { Communication with God or angels and spirit guides (Canda \& } \\
\text { Furman, 1999). }\end{array}$ \\
\hline $\begin{array}{l}\text { Exceptional normal } \\
\text { experiences (EHEs) }\end{array}$ & $\begin{array}{l}\text { Not considered anomalous. Many factors associated with the more } \\
\text { unusual EHEs are present in these experiences, e.g. tears, goose } \\
\text { bumps, a crisis of identity and feeling "wonderstruck" (White, } \\
\text { 1998:134). } \\
\text { Other examples include extraordinary dreams; inspiration of all } \\
\text { types; aesthetic and literary experiences; witnessing or encountering } \\
\text { art, architectural, religious, historical, and other cultural relics, music } \\
\text { and literature and the performance of noble deeds (White, 1998). }\end{array}$ \\
\hline Other & $\begin{array}{l}\text { Out of body experiences (Lukoff \& Lu, 1988; Tart, 1967; Tart, 1968; } \\
\text { Tart, 1995; Wong \& McKeen, 1980). Oneness with the universe or } \\
\text { ultimate reality; remembrance of past incarnations (Canda \& } \\
\text { Furman, 1999). }\end{array}$ \\
\hline
\end{tabular}

\section{THE IMPACT OF TRANSPERSONAL EXPERIENCES AND IMPLICATIONS FOR SOCIAL WORK PRACTICE}

Transpersonal experiences have a mysterious nature and can bring with them either a profound spiritual experience or create a disturbing impact on the person who has had them (Bhagwan, 2002). Clients who have experiences with angels and other spiritual entities may be reluctant to share them with others for fear of being thought of as crazy (Bloomfield, 1980). Religious 
visions, trances and paranormal events even appear "bizarre" to social workers unfamiliar with spiritual crises (Canda, 1988b:246).

Social workers who lack knowledge of the transpersonal paradigm may therefore interpret such experiences as mental dysfunction, confusing genuine experiences of self-transcendence with regressive pathology, to the detriment of the client (Walsh \& Vaughan, 1980; Vaughan, 1991; Canda, 1988b; Cowley, 1993). Cowley (2001:81) noted that there is a "proclivity among mental health professionals to view mystical experience as psychotic episodes". When practitioners do not share the spiritual worldview of the client, the danger of bias is increased.

The Religious or Spiritual Problem Code V, as per The Diagnostic and Statistical Manual of Mental Disorders (American Psychiatric Association, 2000) acknowledges that, although issues pertaining to religious or spiritual growth may require clinical intervention, they may not necessarily be pathological problems. Transpersonal experiences that do not contain features of psychopathology therefore need to be seen in the context of the client's spiritual development journey and affirmed as such. There is evidence that recognising, owning, honouring and sharing exceptional human experiences are beneficial to an individual's health, psychological wellbeing, relationships, lifestyle and philosophy (Braud, 1998; White, 1998; Walsh \& Vaughan, 1980; Driver, 1991).

In order to highlight potential case scenarios the following two examples are presented. This is followed by guidelines on how to manage and assess the transpersonal experience in the therapeutic dialogue.

\section{Case examples}

- A 21-year-old African student, who is HIV positive, indicates to her social worker that she prays regularly to cope with her challenges. She reports that during prayer she sees and hears her ancestors speak to her. She indicates that at times when she is deep in prayer she feels herself being taken back in time, by a divine force, where she participates in ancient traditional African rituals. When she returns she feels a sense of renewal and believes that this gives her a great sense of strength to cope with her problems.

- A 34-year-old Hindu woman, who is severely traumatised after being beaten by her husband, says that she has become spiritual in order to heal. During therapy she tells her social worker that she has visions of divine Hindu figures, which speak to her whenever she feels afraid. According to her, these figures give her much solace and comfort. She reports that she receives guidance through these figures and believes intuitively that they represent a Divine healing force in her life.

Transpersonal experiences that are normal within certain cultural, religious, or spiritual contexts have the potential to be viewed as abnormal in Western contexts. Clients' transpersonal experiences have to be understood within the distinct and unique spiritual or religious worldview of the client. Whilst to the Western practitioner the cases highlighted may appear abnormal, they may in fact be the norm within the client's worldview. Mbiti (1975), for example, wrote that African traditional religion is based on prayer to ancestors for guidance and healing and traditional rituals are important within this framework. African culture also tends to be more oriented "to the soul and spirit energies" (Pearson, in Freeman, 2001:97). For this client, then, the transpersonal experience of contact with her ancestors and being taken back into time to participate in traditional rituals may have been a spiritual experience, which brought her strength and comfort. Similarly, whilst they may appear beyond the norm, religious visions, sightings of certain Hindu holy figures and divine guidance during devotional group singing or meditation are 
not uncommon in Hindu contexts (Sandweiss, 1985; Schumann, 1999). In such instances these transpersonal experiences need to be affirmed rather than being viewed as potentially pathological.

One of the reasons for scepticism and confusion around transpersonal experiences is that spiritual and religious themes are often manifested in psychosis (Hodge, 2004). Transpersonal or intense spiritual experiences mirror features of psychopathology because they involve dramatic changes of states of consciousness, inner voices and extraordinary thoughts and feelings (Lukoff, 1985; Liester, 1996; Heery, 1989), thus easily leading the social worker to believe that a transpersonal experience may be a manifestation of psychopathology. Care thus needs to be undertaken in assessment or else the client's wellbeing may be at risk. Although there are limited guidelines in the literature with regard to discerning spiritual experiences from psychopathology, there are some guiding principles; for example, although transpersonal experiences involve dramatic changes of states of consciousness and extraordinary thoughts, in contrast to mental disorders, they have a sudden onset, limited duration and bring about temporary distress (Liester, 1996; Canda \& Furman, 1999). It is at this point that Wilber's model (1982) and the features outlined by transpersonalists with regard to trans-egoic development become relevant to understanding the experience.

\section{GUIDELINES FOR THE PRACTITIONER}

Social workers should relate to transpersonal experiences with empathy, respect, care and a nonjudgmental attitude of the client's spiritual beliefs, practices and experiences (Cascio, 1998; Canda, 1988a; Canda, 1988b). Reassurance, support and understanding must be provided, especially where the client appears confused, overwhelmed or afraid. This level of spiritual sensitivity may serve to remove barriers to transpersonal awakening or personal transformation (Leight, 2001) and enable disclosure of transpersonal experiences without fear of being disbelieved. The practitioner should not attempt to question the validity of the transpersonal experience, but rather allow for a full sharing of the experience and its impact. This should be done whilst ensuring that the client and significant others are not in danger as a result of the experience (Canda \& Furman, 1999).

It is important to identify the type of transpersonal experience, to ascertain what occurred, when, where and with whom. The social worker should also probe as to whether it was a first time experience, its duration, the client's level of involvement in religion and spirituality, and the meaning and significance of the experience within the clients' broader religious or spiritual framework and life experience. The impact of the experience on the client's overall biopsychosocial and spiritual functioning as well as the impact on significant others also needs to be explored. The social worker may also probe how the experience fits with the client's broader spiritual goals. It is also important to establish whether the experience occurred during prayer, meditation, participation in a religious or spiritual ritual, participation at religious service, reading of religious or spiritual literature, poetry or when listening to spiritual music. Finally, questioning should also probe whether there are benefits to the experience, such as renewed spiritual direction, positive energy or an uplifted spirit, assistance with understanding personal/family problems, stronger psycho-social coping abilities or other goals in terms of spiritual development (Canda \& Furman, 1999). Where there is a history of substance abuse or a chronic mental disorder, care needs to be exercised in differentiating the experience from these problems.

Where transpersonal experiences do not cause major psychosocial upheaval, they can be easily integrated into the client's spiritual life. Whilst practitioners may not have to agree with any 
particular worldview, they can incorporate it into "the full spectrum of the client's life experience" (Vaughan, 1979:72). The transpersonal experience can be viewed as a significant spiritual strength in the life of the client and in their spiritual development (Hodge, 2005; Hodge $\&$ Williams, 2002). The client may also be referred to traditional or spiritual leaders, local faithbased groups or clergy to provide greater insight into the experience and to enable its further integration into their spiritual journey.

\section{CONCLUSION}

The transpersonal paradigm fits well within the parameters of social work practice, because it honours the spiritual and transpersonal dimensions within the holistic bio-psycho-social gestalt. As interest in spirituality gains momentum, it can be expected that a greater number of clients will bring issues of spiritual growth and transformation into the therapeutic realm. In the absence of education and training with regard to transpersonal theory (Bhagwan, 2002) and gaps in the literature with regard to spirituality, practitioners may be more challenged when confronted with the spiritual aspects of their client's lives. Transpersonal experiences are "transrational" or beyond reason within the context of assessment in social work's conventional paradigms (Leight, 2001:71). Practitioners therefore require some knowledge of such experiences and skill with regard to making sense of it within the client's worldview. Cowley (2001) wrote that, whilst it may be tempting to ignore unfamiliar concepts of transpersonal theory, they have relevance to the client systems that we serve.

Leight (2001) rightly stated that transpersonal experiences are not the goal of therapy, but should be seen as potential resources for growth and empowerment. Transpersonal social work offers this expanded conceptual base that will enable practitioners to understand spirituality as it intersects with the bio-psycho-social realms of the person-in-environment context. It is hoped that this article will draw attention to this emerging field and will enable a transcendence of thought that will result in a more holistic and spiritually sensitive approach to the clients we serve.

\section{REFERENCES}

AMERICAN PSYCHIATRIC ASSOCIATION. 2000. Diagnostic and statistical manual of mental disorders $\left(4^{\text {th }}\right.$ ed $)$. Washington DC: APA.

BERENSON, D. 1987. Alcoholics Anonymous: From surrender to transformation. Family Therapy Networker, 11(4):25-31.

BESTHORN, F.H. 2001. Transpersonal psychology and deep ecological philosophy: Exploring linkages and applications for social work. In: CANDA, E.R. \& SMITH E.D. (eds) Transpersonal perspectives on spirituality in social work. New York: The Haworth Press Inc.

BHAGWAN, R. 2002. The role of religion and spirituality in social work practice: Guidelines for curricula development at SA Schools of Social Work. Durban: University of Natal. (DPhil Thesis)

BLOOMFIELD, H.H. 1980. Transcendental meditation as an adjunct to therapy. In: BOORSTEIN, S. (ed) Transpersonal psychotherapy. Palo Alto, Ca: Science and Behavior Books, Inc.

BRAUD, W. 1998. Integral inquiry: Complementary ways of knowing, being and expression. In: BRAUD, W. \& ANDERSON, A. (eds) Transpersonal research methods for the social sciences. California: Sage Publications.

BULLIS, R.K. 1996. Spirituality in social work practice. Washington, DC: Taylor and Francis. 
CANDA, E.R. 1988a. Conceptualising spirituality for social work: Insights from diverse perspectives. Social Thought, 13(1):30-46.

CANDA, E.R. 1988b. Spirituality, religious diversity and social work practice. Social Casework, 69(4):238-247.

CANDA E.R. 2001. Transcending through disability and death: Transpersonal themes in living with cystic fibrosis. In: CANDA, E.R. \& SMITH E.D. (eds) Transpersonal perspectives on spirituality in social work. New York: The Haworth Press Inc.

CANDA, E.R. \& FURMAN, L.D. 1999. Spiritual diversity in social work practice: The heart of helping. New York: The Free Press.

CARROLL, M.M. 2001. Conceptual models of spirituality. In: CANDA, E.R. \& SMITH, E.D. (eds) Transpersonal perspectives on spirituality in social work. New York: The Haworth Press Inc.

CASCIO, T. 1998. Incorporating spirituality into social work practice: A review of what to do. Families in Society, 79:523-531.

COWLEY, A.S. 1993. Transpersonal social work: A theory for the 1990s. Social Work, 38(5):527-534.

COWLEY, A.S. 1996. Transpersonal practice: A fourth force. In: TURNER, F. (ed) Social work treatment: Interlocking theoretical approaches $\left(4^{\text {th }}\right.$ ed). New York: The Free Press.

COWLEY, A.S. 1999. Transpersonal theory and Social work practice with couples and families. Journal of Family Social Work, 3(2):5-21.

COWLEY, A.S. 2001. Cosmic consciousness ; path or pathology? In: CANDA, E.R. \& SMITH, E.D. (eds) Transpersonal perspectives on spirituality in social work. New York: The Haworth Press Inc.

COWLEY, A.S. \& DEREZOTES, D. 1994. Transpersonal psychology and social work education. Journal of Social Work Education, 30(1):1-10.

DEREZOTES, D. 2001. Transpersonal social work with couples; a compatibility-intimacy model. In: CANDA, E.R. \& SMITH, E.D. (eds) Transpersonal perspectives on spirituality in social work. New York: The Haworth Press Inc.

DRIVER, T.F. 1991. The magic of ritual: Our need for liberating rites that transform our lives and our communities. San Francisco: Harper.

ELLISON, C.W. 1983. Spiritual well being: Conceptualisation and measurement. Journal of Psychology and Theology, 11(4):330-340.

FREEMAN, D.R. 2001. The relationship between spiritual development and ethnicity in violent men. In: CANDA, E.R. \& SMITH, E.D. (eds) Transpersonal perspectives on spirituality in social work. New York: The Haworth Press Inc.

HEERY, M.W. 1989. Inner voice experiences: An exploratory study of thirty cases. The Journal of Transpersonal Psychology, 28(1):73-82.

HODGE, D.R. 2004. Spirituality and people with mental illness: Developing spiritual competency in assessment and intervention. Families in Society, 85:36-44.

HODGE, D.R. 2005. Spiritual ecograms: A new assessment instrument for identifying clients' strengths in space and across time. Families in Society, 86(2):287-297. 
HODGE, D.R. \& WILLIAMS, T.R. 2002. Assessing African American spirituality with spiritual eco-maps. Families in Society, 83(5/6):585-596.

LAJOIE, D.H. \& SHAPIRO, S.I. 1992. Definitions of transpersonal psychology: The first twenty-three years. The Journal of Transpersonal Psychology, 24(1):79-98.

LEIGHT, A.K. 2001. Transpersonalism and social work practice: Awakening to new dimensions for client self-determination, empowerment and growth. In: CANDA, E.R. \& SMITH, E.D. (eds) Transpersonal perspectives on spirituality in social work. New York: The Haworth Press Inc.

LIESTER, M.B. 1996. Inner voices: Distinguishing transcendent and pathological characteristics. Journal of Transpersonal Psychology, 28(1):1-30.

LUKOFF, D. 1985. The diagnosis of mystical experiences with psychotic features. The Journal of Transpersonal Psychology, 17(2):155-181.

LUKOFF, D. \& LU, F.G. 1988. Transpersonal psychology research review: Mystical experience. The Journal of Transpersonal Psychology, 20(2):161-184.

MASLOW, A. 1970. Religions, values, and peak experiences. New York: Viking.

MBITI, J.S. 1975. Introduction to African religion. London: Heinemann.

PARGAMENT, K.I. 1997. The psychology of religion and coping: Theory, research, practice. New York: Guildford Press.

REESE, D.J. 2001. Addressing spirituality in hospice: Current practices and a proposed role for transpersonal social work. In: CANDA, E.R. \& SMITH, E.D. (eds) Transpersonal perspectives on spirituality in social work. New York: The Haworth Press Inc.

RING, K. 1984. Heading Towards Omega. New York: Morrow.

ROTHBERG, D. \& KELLY, S. 1998. Ken Wilber in dialogue: Conversations with leading transpersonal thinkers. USA: Theosophical Publishing House.

SANDWEISS, S.H. 1985. Spirit and the mind. India: Sri Sathya Sai Books and Publications Trust.

SCHUMANN, E. 1999. Mind into Heart. India: Message Publications.

SMITH, E.D. 1995. Addressing the psycho-spiritual distress of death as reality: A transpersonal approach. Social Work, 40:402-412.

SMITH, E.D. 2001. Alleviating suffering in the face of death; insights from constructivism and a transpersonal narrative approach. In: CANDA, E.R. \& SMITH, E.D. (eds) Transpersonal perspectives on spirituality in social work. New York: The Haworth Press Inc.

TART, C. 1967. A second psycho-physiological study of out of the body experiences in a gifted subject. International Journal of Parapsychology, 9:251-258.

TART, C. 1968. A psycho-physiological study of the out of the body experiences in a selected subject. Journal of the American Society for Psychical Research, 62:3-27.

TART, C. 1995. Toward the objective exploration of non-ordinary reality. The Journal of Transpersonal Psychology, 27(1):57-67.

VAUGHAN, F. 1979. Transpersonal psychotherapy: Context, content and process. The Journal of Transpersonal Psychology, 11(2):101-110. 
VAUGHAN, F. 1987. A question of balance: Health and pathology in new religious movements. In: ANTHONY, D., ECKER, B., \& WILBER, L. (eds) Spiritual choices: The problem of recognizing authentic paths to inner transformation. New York: Paragon House Publishers.

VAUGHAN, F. 1991. Spiritual issues in psychotherapy. The Journal of Transpersonal Psychology, 23(2):105-117.

VAUGHAN, F. 1993. Healing and wholeness: Transpersonal psychotherapy. In: WALSH, R. \& VAUGHAN, E. (eds) Paths beyond ego: The transpersonal vision. Los Angeles: Tarcher/ Perigee.

WALSH, R.N. \& VAUGHAN, F.E. 1980. Comparative models of the person and psychotherapy. In: BOORSTEIN, S. (ed) Transpersonal psychotherapy. Palo Alto, Ca: Science and Behaviour Books Inc.

WASHBURN, M. 1988. The ego and the dynamic ground. New York: University of New York Press.

WHITE, R.A. 1998. Becoming more human as we work: The reflexive role of exceptional human experience. In: BRAUD, W. \& ANDERSON, A. (eds) Transpersonal research methods for the social sciences. California: Sage Publications.

WILBER, K. 1979. A developmental view of consciousness. The Journal of Transpersonal Psychology, 11(1):1-21.

WILBER, K. 1982. The Pre/Trans Fallacy. Journal of Humanistic Psychology, 22:57-90.

WILBER, K., ENGLER, J. \& BROWN, D. 1986. Transformations of consciousness. Boston: Shambala.

WONG, B.R. \& McKEEN, J. 1980. Transpersonal experience through body approaches. In: BOORSTEIN, S. (ed) Transpersonal psychotherapy. Palo Alto, Ca: Science and Behaviour Books, Inc.

Dr Raisuyah Bhagwan, Lecturer, Department of Child and Youth Care, Durban University of Technology, Durban, South Africa. 